\title{
Communication
}

\section{The Effect of Lifestyle Intervention on Diabetes Prevention by Ethnicity: A Systematic Review of Intervention Characteristics Using the TIDieR Framework}

\author{
Mingling Chen ${ }^{1}{ }^{\oplus}$, Gebresilasea Gendisha Ukke ${ }^{1}{ }^{\circledR}$, Lisa J. Moran ${ }^{1}$, Surbhi Sood ${ }^{1}$, Christie J. Bennett ${ }^{2} \mathbb{D}$, \\ Mahnaz Bahri Khomami ${ }^{1}$, Pilvikki Absetz ${ }^{3}{ }^{-}$, Helena Teede ${ }^{1,4}{ }^{-}$, Cheryce L. Harrison ${ }^{1,4, \dagger}$ and Siew Lim ${ }^{1, *,+}$ \\ 1 Monash Centre for Health Research and Implementation, School of Public Health and Preventive Medicine, \\ Monash University, Clayton, VIC 3168, Australia; mingling.chen@monash.edu (M.C.); \\ gebretecno@gmail.com (G.G.U.); Lisa.Moran@monash.edu (L.J.M.); sood.surbhi@icloud.com (S.S.); \\ mahnaz.bahri-khomami@monash.edu (M.B.K.); helena.teede@monash.edu (H.T.); \\ Cheryce.Harrison@monash.edu (C.L.H.) \\ 2 Department of Nutrition, Dietetics and Food, School of Clinical Sciences, Monash University, \\ Notting Hill, VIC 3168, Australia; Christie.Bennett@monash.edu \\ 3 Faculty of Social Sciences, Tampere University, 33014 Tampere, Finland; pilvikki.absetz@gmail.com \\ 4 Diabetes and Endocrine Unit, Monash Health, Clayton, VIC 3168, Australia \\ * Correspondence: siew.lim1@monash.edu; Tel.: +61-447-558-686 \\ + These authors contributed equally to this work.
}

\section{check for}

updates

Citation: Chen, M.; Ukke, G.G.; Moran, L.J.; Sood, S.; Bennett, C.J.; Bahri Khomami, M.; Absetz, P.; Teede, H.; Harrison, C.L.; Lim, S. The Effect of Lifestyle Intervention on Diabetes Prevention by Ethnicity: A Systematic Review of Intervention Characteristics Using the TIDieR Framework. Nutrients 2021, 13, 4118. https://doi.org/10.3390/nu13114118

Academic Editor: Antonio Brunetti

Received: 24 September 2021

Accepted: 12 November 2021

Published: 17 November 2021

Publisher's Note: MDPI stays neutral with regard to jurisdictional claims in published maps and institutional affiliations.

Copyright: (c) 2021 by the authors. Licensee MDPI, Basel, Switzerland This article is an open access article distributed under the terms and conditions of the Creative Commons Attribution (CC BY) license (https:// creativecommons.org/licenses/by/ $4.0 /)$.

\begin{abstract}
Lifestyle intervention is effective in preventing type 2 diabetes mellitus (T2DM), but the efficacy of intervention components across different ethnic groups is less clear. This systematic review examined the effects of intervention characteristics of lifestyle interventions on diabetes incidence and weight loss by ethnicity using the Template for Intervention Description and Replication (TIDieR) framework. MEDLINE, EMBASE and other databases were searched for randomized and nonrandomized controlled trials on lifestyle interventions (diet and/or physical activity) in adults at risk of T2DM. Ethnicity was categorized into European, South Asian, East and Southeast Asian, Middle Eastern, Latin American and African groups. Forty-five studies (18,789 participants) were included in the systematic review and 41 studies in meta-analysis. Meta-analysis showed a high number of intervention sessions was significantly associated with a greater reduction in diabetes incidence $(P=0.043)$ and weight $(P=0.015)$, while other intervention characteristics including intervention provider and delivery format did not alter the outcomes (all $P>0.05$ ). Additionally, narrative synthesis showed long-term interventions ( $\geq 12$ months) were associated with significant diabetes risk reduction for all ethnic groups, while short-term interventions ( $<12$ months) were more effective in weight loss in most ethnic groups. There may be ethnic preferences for the optimal number of intervention sessions.
\end{abstract}

Keywords: ethnicity; lifestyle intervention; systematic review; type 2 diabetes

\section{Introduction}

Type 2 diabetes mellitus (T2DM) is a major global health concern [1]. The prevalence of T2DM varies widely by ethnicity [2]. For example, in the US, American Indians/Alaska Natives have the highest prevalence of diagnosed diabetes $(14.7 \%)$, followed by Hispanic $(12.5 \%)$, African (11.7\%), Asian (9.2\%) and white Americans (7.5\%) [3]. Lifestyle modification has been demonstrated to prevent T2DM by up to $58 \%$ in high-risk individuals through increased physical activity, healthy diet, and weight management [4-7]. Adaptation and translation of lifestyle interventions for broad population benefit are underway around the world in an attempt to address the diabetes epidemic. A recent meta-analysis showed lifestyle interventions had similar effects in reducing T2DM incidence across ethnic groups, but ethnic differences were found in weight loss achieved [8]. Ethnicity is a social construct 
that refers to the cultural identity of a group of people including languages, customs and religions [9]. Effective engagement strategies may differ across ethnic groups, necessitating cultural adaptations of diabetes prevention programs $[10,11]$. Identification of the determinants of intervention success is required to inform implementation and practice [12]. While effective intervention characteristics have been identified for T2DM prevention in the general population, including number of sessions delivered, intervention duration and adherence to guidelines [13-17], these have not been systematically investigated across various ethnic groups. Understanding the optimal intervention strategies within the specific ethnic groups is imperative to guide cultural adaptations and future scale-up of diabetes prevention programs.

Intervention characteristics can be systematically described using the Template for Intervention Description and Replication (TIDieR) framework, which was originally developed to improve the reporting of intervention studies [18]. Therefore, this systematic review aimed to examine the intervention characteristics of lifestyle interventions associated with T2DM prevention in different ethnic groups using the TIDieR framework.

\section{Materials and Methods}

This is a secondary analysis of our recent systematic review on ethnic differences in lifestyle intervention effects on T2DM prevention in adults [8]. The protocol was prospectively registered on PROSPERO (No. CRD42020193503). A comprehensive search was conducted in MEDLINE, EMBASE, Pubmed, CINAHL, PsycInfo, Cochrane Central Register of Controlled Trials, EBM Reviews and the International Clinical Trials Registry Platform with no language restriction for articles published up to June 2020. The search strategy has been previously described [8]. Inclusion criteria were randomized controlled trials (RCTs) and non-randomized controlled trials (non-RCTs) that compared lifestyle intervention/s (diet, physical activity or both) with a control group (usual care, placebo, no intervention or minimal intervention) on T2DM prevention; participants aged $\geq 18$ years and at risk of T2DM (e.g., prediabetes, overweight or obesity, history of gestational diabetes, elevated diabetes risk score); and reporting at least one of the following outcomes by ethnicity: diabetes incidence (defined as fasting glucose $\geq 7.0 \mathrm{mmol} / \mathrm{L}$, and / or 2-h glucose $\geq 11.1 \mathrm{mmol} / \mathrm{L}$, and / or $\mathrm{HbA}_{1 \mathrm{c}} \geq 6.5 \%$, or clinical diagnosis by a physician), fasting glucose, 2-h glucose, $\mathrm{HbA}_{1 \mathrm{c}}$, body weight, body mass index (BMI), waist circumference, physical activity, energy intake, energy from fat and fibre intake. All editorials, letters, commentaries, protocols, conference abstracts, dissertations and reviews were excluded.

The primary outcomes of this analysis were diabetes risk reduction (absolute or relative risk reduction) and weight loss (mean or median loss) measured at the end of the intervention. Intervention characteristics were extracted according to the TIDieR checklist [18] including why (theoretical framework), what (intervention type), who (intervention provider), how (delivery format, use of technology), where (intervention location), when (intervention duration), how much (number of intervention sessions), tailoring (i.e., personalized intervention) and how well (fidelity). Table S1 shows the coding of the TIDieR components. Intervention duration was defined as short ( $<12$ months) or long ( $\geq 12$ months). The total number of intervention sessions was classified as low ( $\leq 15$ sessions) or high ( $\geq 16$ sessions) according to the median. Ethnicity was extracted as described in the included studies and subsequently categorized into European, South Asian, East and Southeast Asian, Middle Eastern, Latin American and African groups based on the World Bank regions [19]. No eligible studies on Indigenous populations were identified. The risk of bias of RCTs and non-RCTs was assessed using the Revised Cochrane Risk of Bias tool for Randomized Trials (RoB 2) [20] and the Risk of Bias in Non-randomized Studies of Interventions (ROBINS-I) tool [21], respectively. Two reviewers independently screened the articles (M.C., G.G.U., S.S. and C.J.B.), extracted the data (M.C., G.G.U., S.S. and M.B.K.) and assessed study quality (M.C. and C.J.B.). Any discrepancies were resolved by discussion or arbitration with a third reviewer (S.L.). 
Risk ratios (RRs) for diabetes incidence and mean differences (MDs) for body weight were pooled using random-effects meta-analysis. Subgroup analyses by TIDieR components were conducted to assess the effect of intervention characteristics on the outcomes. Due to insufficient studies for meta-analysis, the associations between intervention characteristics and the outcomes by ethnicity were summarized narratively. Publication bias was assessed with funnel plots and Egger's tests. Analyses were performed using R version 4.0.3 (Free Software Foundation, Inc. 1991, 1999, Boston, MA, USA).

\section{Results}

\subsection{Identified Studies}

From 17,374 articles, 62 articles representing 45 studies met the inclusion criteria. Of these, 41 studies with complete outcome data were included in meta-analyses (Figure S1). The 45 included studies enrolled 18,789 participants (53\% female, mean age 32.8 to 63.9 years) across 14 countries. Most of the studies included participants from the European group $(n=12)$, followed by South Asian $(n=10)$, East and Southeast Asian $(n=10)$, Middle Eastern $(n=4)$, Latin American $(n=3)$ and African groups $(n=2)$. Four studies included more than one ethnic group [4,22-24].

\subsection{Intervention Characteristics}

The intervention characteristics according to the TIDieR checklist are summarized in Table S2. Thirty-four studies provided a theoretical framework for the intervention, mostly the social cognitive theory, the transtheoretical model and the health action process approach. The remaining studies did not report the theory used to underpin the intervention. All studies utilized a combined diet and physical activity intervention, with the exception of one, diet only intervention [25]. Thirty-three studies involved health professionals as the intervention provider (e.g., dietitian, nurse, physician, physiotherapist, healthcare worker), while interventions in the rest studies were provided by non-health professionals (e.g., community health worker, peer educator) or automatically delivered via website or mobile phone. Twelve studies delivered the interventions individually, 12 studies in a group format, and 21 studies employed a combination of individual and group formats. Twenty-six studies utilized technology in the delivery of interventions, through telephone, mobile phone, website, video, email, fax or surface mail. Ten studies had interventions offered in researcher-based locations (e.g., hospital, clinic, research institute) and 25 studies at participants' home and surroundings (e.g., community setting, school, temple) or workplaces. The intervention duration ranged from 1.5 [26] to 72 [5] months. The total number of intervention sessions ranged from 1 [27] to 78 [28]. Most interventions $(n=34)$ were tailored through personalized goals or plans. Over half of the studies $(n=25)$ had a high level of intervention fidelity.

\subsection{Risk of Bias Assessment}

All studies had an overall high risk of bias, except two with some concerns [29,30] and three with low risk of bias [31-33]. The overall high risk of bias was mainly derived from the bias in deviations from intended interventions due to low adherence to the interventions (less than $80 \%$ of participants completing intervention sessions or intervention components). For the rest domains of the RoB 2 and ROBINS-I tools, most studies were rated as low risk of bias or some concerns, as described previously [8].

\subsection{Intervention Effects}

Meta-analyses showed lifestyle interventions resulted in significant improvement in diabetes incidence (RR $0.71,95 \% \mathrm{CI}[0.64,0.79], \mathrm{I}^{2}=23.4 \%$ ) and body weight (MD $-2.13 \mathrm{~kg}$, $95 \%$ CI $[-2.71,-1.54], I^{2}=86.7 \%$ ) compared to control groups. Subgroup analyses by TIDieR components showed interventions with high number of sessions had a significantly greater reduction in diabetes incidence (RR 95\%CI: 0.66 [0.57, 0.77] vs. 0.79 [0.69, 0.91], $P=0.043$ ) and body weight (MD 95\%CI: $-2.79 \mathrm{~kg}[-3.58,-2.01]$ vs. $-1.48 \mathrm{~kg}[-2.29$, 
$-0.66], P=0.015)$ than those with low number of sessions (Tables 1 and 2). None of the other TIDieR components were significantly associated with the outcomes (all $P>0.05$ ).

Table 1. Subgroup analyses of lifestyle intervention on diabetes incidence by TIDieR components.

\begin{tabular}{|c|c|c|c|c|}
\hline TIDieR Components & Studies ${ }^{a}$ & Risk Ratio (95\%CI) & $I^{2}(\%)$ & $P$ for Subgroup Differences \\
\hline Use of theory & & & & 0.958 \\
\hline Yes & 18 & $0.71(0.59,0.85)$ & 32.5 & \\
\hline No & 7 & $0.71(0.61,0.81)$ & 6.7 & \\
\hline Intervention provider & & & & 0.334 \\
\hline With health professional & 16 & $0.73(0.65,0.81)$ & 5.6 & \\
\hline Without health professional & 9 & $0.65(0.48,0.87)$ & 56.0 & \\
\hline Intervention duration & & & & 0.538 \\
\hline Short (<12 months) & 9 & $0.64(0.40,1.02)$ & 0.0 & \\
\hline Long ( $\geq 12$ months) & 16 & $0.71(0.62,0.81)$ & 40.3 & \\
\hline Number of sessions & & & & 0.043 \\
\hline Low $(\leq 15$ sessions $)$ & 12 & $0.79(0.69,0.91)$ & 0.0 & \\
\hline High $(\geq 16$ sessions $)$ & 13 & $0.66(0.57,0.77)$ & 31.9 & \\
\hline Delivery format & & & & 0.492 \\
\hline Group & 5 & $0.71(0.50,1.00)$ & 55.3 & \\
\hline Individual & 11 & $0.77(0.67,0.88)$ & 0.0 & \\
\hline Combined & 9 & $0.66(0.48,0.90)$ & 31.9 & \\
\hline Technology (e.g., phone, website) & & & & 0.177 \\
\hline With technology & 14 & $0.77(0.67,0.90)$ & 2.7 & \\
\hline In-person only & 11 & $0.68(0.57,0.80)$ & 32.0 & \\
\hline Location of intervention & & & & 0.899 \\
\hline Researcher-based & 7 & $0.70(0.60,0.82)$ & 7.9 & \\
\hline Participant-based & 16 & $0.69(0.58,0.83)$ & 33.3 & \\
\hline Combined & 2 & $0.79(0.03,19.21)$ & 42.6 & \\
\hline Tailoring & & & & 0.224 \\
\hline Yes & 19 & $0.70(0.60,0.81)$ & 40.6 & \\
\hline No & 6 & $0.77(0.71,0.83)$ & 0.0 & \\
\hline Fidelity & & & & 0.868 \\
\hline Low /medium & 10 & $0.70(0.64,0.78)$ & 0.0 & \\
\hline High & 15 & $0.72(0.57,0.89)$ & 45.5 & \\
\hline
\end{tabular}

${ }^{a}$ Number of studies by ethnic groups.

Table 2. Subgroup analyses of lifestyle intervention on body weight by TIDieR components.

\begin{tabular}{|c|c|c|c|c|}
\hline TIDieR Components & Studies ${ }^{a}$ & $\begin{array}{l}\text { Mean Difference, kg } \\
(95 \% \mathrm{CI})\end{array}$ & $I^{2}(\%)$ & $P$ for Subgroup Differences \\
\hline Use of theory & & & & 0.280 \\
\hline Yes & 34 & $-2.25(-2.94,-1.55)$ & 88.5 & \\
\hline No & 8 & $-1.63(-2.71,-0.55)$ & 60.1 & \\
\hline Intervention provider & & & & 0.395 \\
\hline With health professional & 30 & $-2.27(-3.02,-1.51)$ & 89.5 & \\
\hline Without health professional & 12 & $-1.79(-2.71,-0.87)$ & 64.3 & \\
\hline Intervention duration & & & & 0.404 \\
\hline Short (<12 months) & 25 & $-2.34(-3.12,-1.55)$ & 80.4 & \\
\hline Long ( $\geq 12$ months) & 17 & $-1.85(-2.79,-0.90)$ & 90.3 & \\
\hline Number of sessions & & & & 0.015 \\
\hline Low ( $\leq 15$ sessions $)$ & 23 & $-1.48(-2.29,-0.66)$ & 85.0 & \\
\hline High ( $\geq 16$ sessions $)$ & 19 & $-2.79(-3.58,-2.01)$ & 82.6 & \\
\hline Delivery format & & & & 0.996 \\
\hline Group & 12 & $-2.15(-3.55,-0.75)$ & 91.9 & \\
\hline Individual & 9 & $-2.09(-3.19,-0.98)$ & 69.5 & \\
\hline Combined & 21 & $-2.13(-3.01,-1.24)$ & 84.6 & \\
\hline Technology (e.g., phone, website) & & & & 0.590 \\
\hline With technology & 26 & $-2.25(-2.98,-1.53)$ & 83.6 & \\
\hline In-person only & 16 & $-1.92(-3.02,-0.81)$ & 89.1 & \\
\hline
\end{tabular}


Table 2. Cont.

\begin{tabular}{|c|c|c|c|c|}
\hline TIDieR Components & Studies ${ }^{a}$ & $\begin{array}{c}\text { Mean Difference, kg } \\
(95 \% \mathrm{CI})\end{array}$ & $I^{2}(\%)$ & $P$ for Subgroup Differences \\
\hline Location of intervention & & & & 0.096 \\
\hline Researcher-based & 8 & $-1.46(-1.97,-0.94)$ & 16.0 & \\
\hline Participant-based & 24 & $-2.31(-3.11,-1.51)$ & 88.1 & \\
\hline Combined & 10 & $-2.39(-4.04,-0.74)$ & 90.9 & \\
\hline Tailoring & & & & 0.911 \\
\hline Yes & 31 & $-2.11(-2.84,-1.38)$ & 87.4 & \\
\hline No & 11 & $-2.18(-3.26,-1.09)$ & 83.6 & \\
\hline Fidelity & & & & 0.271 \\
\hline Low/medium & 16 & $-1.76(-2.58,-0.94)$ & 74.8 & \\
\hline High & 26 & $-2.37(-3.20,-1.54)$ & 89.6 & \\
\hline
\end{tabular}

${ }^{a}$ Number of studies by ethnic groups.

Table 3 shows the association between intervention characteristics and the outcomes by ethnicity. For diabetes incidence, all studies that reported significant diabetes risk reduction had a high number of sessions ( $\geq 16$ sessions) over a long duration ( $\geq 12$ months), except two studies in the East and Southeast Asian group with a lower number of sessions (13 [33] and 14 sessions [34] respectively). For weight loss, most ethnic groups (i.e., European, South Asian, East and Southeast Asian, Middle Eastern) were more likely to report significant weight loss with interventions of short duration ( $<12$ months). Some ethnic differences were seen in weight loss and number of sessions, in that $80 \%(8 / 10$ studies $)$ of the European group that reported significant weight loss had a high number of sessions, while $80 \%$ (4/5 studies) of the East and Southeast Asian group that reported significant weight loss had a low number of sessions.

Publication bias was found for body weight (Egger's test $P=0.012$ ) but not for diabetes incidence (Egger's test $P=0.115$ ). Funnel plots suggested smaller studies with greater weight loss were less likely to be published (Figure S2). 
Table 3. TIDieR components and the effects of lifestyle intervention on diabetes incidence and body weight by ethnicity.

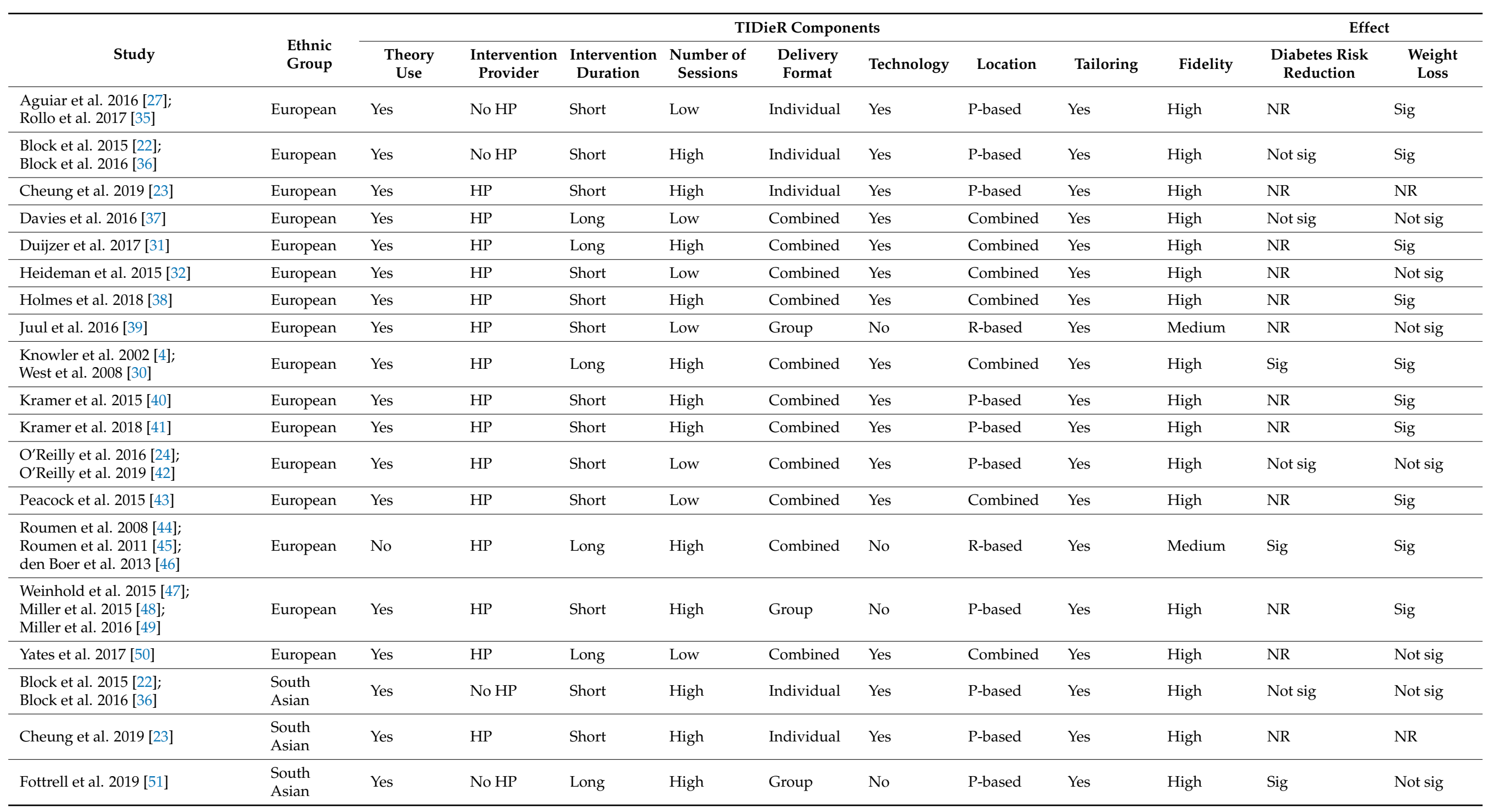


Table 3. Cont.

\begin{tabular}{|c|c|c|c|c|c|c|c|c|c|c|c|c|}
\hline \multirow[b]{2}{*}{ Study } & \multirow[b]{2}{*}{$\begin{array}{l}\text { Ethnic } \\
\text { Group }\end{array}$} & \multicolumn{9}{|c|}{ TIDieR Components } & \multicolumn{2}{|c|}{ Effect } \\
\hline & & $\begin{array}{l}\text { Theory } \\
\text { Use }\end{array}$ & $\begin{array}{c}\text { Intervention } \\
\text { Provider }\end{array}$ & $\begin{array}{l}\text { Intervention } \\
\text { Duration }\end{array}$ & $\begin{array}{l}\text { Number of } \\
\text { Sessions }\end{array}$ & $\begin{array}{c}\text { Delivery } \\
\text { Format }\end{array}$ & Technology & Location & Tailoring & Fidelity & $\begin{array}{c}\text { Diabetes Risk } \\
\text { Reduction }\end{array}$ & $\begin{array}{c}\text { Weight } \\
\text { Loss }\end{array}$ \\
\hline $\begin{array}{l}\text { Islam et al. } 2014 \text { [52]; } \\
\text { Lim et al. } 2019 \text { [53] }\end{array}$ & $\begin{array}{l}\text { South } \\
\text { Asian }\end{array}$ & Yes & No HP & Short & Low & Combined & Yes & P-based & Yes & Medium & NR & Sig \\
\hline Limaye et al. 2017 [54] & $\begin{array}{l}\text { South } \\
\text { Asian }\end{array}$ & No & No HP & Long & High & Individual & Yes & P-based & No & High & NR & Sig \\
\hline Muralidharan et al. 2019 [55] & $\begin{array}{l}\text { South } \\
\text { Asian }\end{array}$ & Yes & $\mathrm{HP}$ & Short & Low & Individual & Yes & P-based & No & High & Not sig & Sig \\
\hline Nanditha et al. 2020 [56] & $\begin{array}{l}\text { South } \\
\text { Asian }\end{array}$ & Yes & No HP & Long & High & Individual & Yes & P-based & Yes & High & Not sig & NR \\
\hline Patel et al. 2017 [57] & $\begin{array}{l}\text { South } \\
\text { Asian }\end{array}$ & Yes & $\mathrm{HP}$ & Short & Low & Group & Yes & P-based & Yes & Medium & NR & Not sig \\
\hline $\begin{array}{l}\text { Ramachandran et al. } 2006 \text { [6]; } \\
\text { Snehalatha et al. } 2008 \text { [58] }\end{array}$ & $\begin{array}{l}\text { South } \\
\text { Asian }\end{array}$ & No & $\mathrm{HP}$ & Long & High & Individual & Yes & P-based & Yes & Low & Sig & Not sig \\
\hline $\begin{array}{l}\text { Ramachandran et al. } 2013 \text { [28]; } \\
\text { Ram et al. } 2014 \text { [59]; } \\
\text { Nanditha et al. 2018 [60] }\end{array}$ & $\begin{array}{l}\text { South } \\
\text { Asian }\end{array}$ & Yes & No HP & Long & High & Individual & Yes & P-based & Yes & High & Sig & NR \\
\hline Weber et al. 2016 [63] & $\begin{array}{l}\text { South } \\
\text { Asian }\end{array}$ & Yes & $\mathrm{HP}$ & Short & High & Group & No & R-based & No & Medium & Not sig & Sig \\
\hline Aekplakorn et al. 2019 [34] & $\begin{array}{l}\text { East and } \\
\text { Southeast } \\
\text { Asian }\end{array}$ & No & $\mathrm{HP}$ & Long & Low & Group & No & R-based & No & Medium & Sig & Sig \\
\hline Bender et al. 2018 [64] & $\begin{array}{l}\text { East and } \\
\text { Southeast } \\
\text { Asian }\end{array}$ & Yes & $\mathrm{HP}$ & Short & Low & Combined & Yes & Combined & Yes & Low & NR & Sig \\
\hline $\begin{array}{l}\text { Block et al. } 2015 \text { [22]; } \\
\text { Block et al. } 2016 \text { [36] }\end{array}$ & $\begin{array}{l}\text { East and } \\
\text { Southeast } \\
\text { Asian }\end{array}$ & Yes & No HP & Short & High & Individual & Yes & P-based & Yes & High & Not sig & Sig \\
\hline Ibrahim et al. 2016 [33] & $\begin{array}{l}\text { East and } \\
\text { Southeast } \\
\text { Asian }\end{array}$ & Yes & $\mathrm{HP}$ & Long & Low & Combined & Yes & P-based & Yes & High & Sig & Sig \\
\hline
\end{tabular}


Table 3. Cont.

\begin{tabular}{|c|c|c|c|c|c|c|c|c|c|c|c|c|}
\hline \multirow[b]{2}{*}{ Study } & \multirow[b]{2}{*}{$\begin{array}{l}\text { Ethnic } \\
\text { Group }\end{array}$} & \multicolumn{9}{|c|}{ TIDieR Components } & \multicolumn{2}{|c|}{ Effect } \\
\hline & & $\begin{array}{l}\text { Theory } \\
\text { Use }\end{array}$ & $\begin{array}{l}\text { Intervention } \\
\text { Provider }\end{array}$ & $\begin{array}{l}\text { Intervention } \\
\text { Duration }\end{array}$ & $\begin{array}{l}\text { Number of } \\
\text { Sessions }\end{array}$ & $\begin{array}{l}\text { Delivery } \\
\text { Format }\end{array}$ & Technology & Location & Tailoring & Fidelity & $\begin{array}{l}\text { Diabetes Risk } \\
\text { Reduction }\end{array}$ & $\begin{array}{c}\text { Weight } \\
\text { Loss }\end{array}$ \\
\hline Inouye et al. 2014 [29] & $\begin{array}{l}\text { East and } \\
\text { Southeast } \\
\text { Asian }\end{array}$ & Yes & $\mathrm{HP}$ & Short & Low & Group & No & P-based & Yes & High & NR & Sig \\
\hline Islam et al. 2013 [65] & $\begin{array}{l}\text { East and } \\
\text { Southeast } \\
\text { Asian }\end{array}$ & Yes & No HP & Short & Low & Combined & Yes & P-based & Yes & Medium & NR & Not sig \\
\hline $\begin{array}{l}\text { Pan et al. } 1995 \text { [67]; } \\
\text { Pan et al. } 1997 \text { [5]; } \\
\text { Li et al. } 2008 \text { [68] }\end{array}$ & $\begin{array}{l}\text { East and } \\
\text { Southeast } \\
\text { Asian }\end{array}$ & No & $\mathrm{HP}$ & Long & High & Combined & No & R-based & Yes & Medium & Sig & Not sig \\
\hline $\begin{array}{l}\text { Sakane et al. } 2011 \text { [69]; } \\
\text { Sakane et al. } 2014 \text { [70] }\end{array}$ & $\begin{array}{l}\text { East and } \\
\text { Southeast } \\
\text { Asian }\end{array}$ & Yes & $\mathrm{HP}$ & Long & Low & Combined & Yes & Combined & Yes & Medium & Not sig & Not sig \\
\hline Shek et al. 2014 [71] & $\begin{array}{l}\text { East and } \\
\text { Southeast } \\
\text { Asian }\end{array}$ & No & $\mathrm{HP}$ & Long & Low & Individual & No & R-based & Yes & Low & Not sig & NR \\
\hline Wong et al. 2013 [72] & $\begin{array}{l}\text { East and } \\
\text { Southeast } \\
\text { Asian }\end{array}$ & Yes & No HP & Long & High & Individual & Yes & P-based & No & High & Not sig & Not sig \\
\hline Abujudeh et al. 2012 [73] & $\begin{array}{l}\text { Middle } \\
\text { Eastern }\end{array}$ & No & $\mathrm{HP}$ & Short & High & Group & No & P-based & No & Low & NR & Sig \\
\hline Al-Hamdan et al. 2019 [74] & $\begin{array}{l}\text { Middle } \\
\text { Eastern }\end{array}$ & No & $\mathrm{HP}$ & Short & Low & Individual & No & R-based & Yes & Low & NR & NR \\
\hline Amer et al. 2020 [75] & $\begin{array}{l}\text { Middle } \\
\text { Eastern }\end{array}$ & No & $\mathrm{HP}$ & Long & Low & Individual & No & R-based & Yes & Low & Not sig & Not sig \\
\hline Zilberman-Kravits et al. 2018 [76] & $\begin{array}{l}\text { Middle } \\
\text { Eastern }\end{array}$ & No & $\mathrm{HP}$ & Long & Low & Combined & No & R-based & No & Low & Not sig & Not sig \\
\hline $\begin{array}{l}\text { Block et al. } 2015 \text { [22]; } \\
\text { Block et al. } 2016 \text { [36] }\end{array}$ & $\begin{array}{l}\text { Latin } \\
\text { American }\end{array}$ & Yes & No HP & Short & High & Individual & Yes & P-based & Yes & High & Not sig & Not sig \\
\hline
\end{tabular}


Table 3. Cont.

\begin{tabular}{|c|c|c|c|c|c|c|c|c|c|c|c|c|}
\hline \multirow[b]{2}{*}{ Study } & \multirow[b]{2}{*}{$\begin{array}{l}\text { Ethnic } \\
\text { Group }\end{array}$} & \multicolumn{9}{|c|}{ TIDieR Components } & \multicolumn{2}{|c|}{ Effect } \\
\hline & & $\begin{array}{l}\text { Theory } \\
\text { Use }\end{array}$ & $\begin{array}{l}\text { Intervention } \\
\text { Provider }\end{array}$ & $\begin{array}{l}\text { Intervention } \\
\text { Duration }\end{array}$ & $\begin{array}{l}\text { Number of } \\
\text { Sessions }\end{array}$ & $\begin{array}{c}\text { Delivery } \\
\text { Format }\end{array}$ & Technology & Location & Tailoring & Fidelity & $\begin{array}{c}\text { Diabetes Risk } \\
\text { Reduction }\end{array}$ & $\begin{array}{c}\text { Weight } \\
\text { Loss }\end{array}$ \\
\hline $\begin{array}{l}\text { Knowler et al. 2002 [4]; } \\
\text { West et al. } 2008 \text { [30] }\end{array}$ & $\begin{array}{l}\text { Latin } \\
\text { American }\end{array}$ & Yes & $\mathrm{HP}$ & Long & High & Combined & Yes & Combined & Yes & High & Sig & Sig \\
\hline Ockene et al. 2012 [77] & $\begin{array}{l}\text { Latin } \\
\text { American }\end{array}$ & Yes & No HP & Long & High & Combined & No & P-based & Yes & High & Not sig & Sig \\
\hline Parikh et al. 2010 [78] & $\begin{array}{l}\text { Latin } \\
\text { American }\end{array}$ & Yes & No HP & Short & Low & Group & No & P-based & No & Medium & Not sig & Sig \\
\hline Van Name et al. 2016 [79] & $\begin{array}{l}\text { Latin } \\
\text { American }\end{array}$ & Yes & $\mathrm{HP}$ & Short & Low & Group & No & P-based & No & Medium & Not sig & Sig \\
\hline $\begin{array}{l}\text { Auslander et al. } 2000 \text { [80]; } \\
\text { Auslander et al. } 2002 \text { [25] }\end{array}$ & African & Yes & No HP & Short & Low & Combined & No & P-based & Yes & High & NR & Not sig \\
\hline Bernstein et al. 2014 [26] & African & No & $\mathrm{HP}$ & Short & Low & Group & No & R-based & No & Medium & NR & Not sig \\
\hline $\begin{array}{l}\text { Knowler et al. 2002 [4]; } \\
\text { West et al. } 2008 \text { [30] }\end{array}$ & African & Yes & $\mathrm{HP}$ & Long & High & Combined & Yes & Combined & Yes & High & Sig & Sig \\
\hline $\begin{array}{l}\text { O'Reilly et al. } 2016 \text { [24]; } \\
\text { O'Reilly et al. } 2019 \text { [42] }\end{array}$ & African & Yes & HP & Short & Low & Combined & Yes & P-based & Yes & High & Not sig & Not sig \\
\hline
\end{tabular}

HP, health professional; P, participant; R, researcher; NR, not reported; Sig, significant reduction in the intervention group compared to the control group $(P<0.05)$. 


\section{Discussion}

This systematic review examined lifestyle intervention characteristics associated with T2DM prevention using the TIDieR framework in different ethnic groups, including in European, South Asian, East and Southeast Asian, Middle Eastern, Latin American and African groups. Meta-analysis showed lifestyle interventions with high number of sessions were significantly associated with a greater reduction in diabetes incidence and body weight. Other intervention characteristics such as intervention provider, delivery format and use of technology did not significantly alter diabetes incidence or body weight, suggesting these may be adapted according to contextual needs. Narrative synthesis showed a relatively high number of sessions over the long term is required to induce a significant diabetes risk reduction for all ethnic groups. Interventions of shorter duration appeared to be more effective in inducing weight loss in most ethnic groups, while the optimal number of sessions for weight loss might vary by ethnicity.

The associations of diabetes incidence and weight loss with number of sessions found in our meta-analyses are consistent with previous systematic reviews of real-world diabetes prevention programs, which showed each session attended was associated with $18 \%$ lower odds of developing T2DM and $26 \%$ or $0.15 \mathrm{~kg}$ more weight loss $[13,16]$. We additionally found across all ethnic groups, interventions that effectively reduced diabetes incidence were of a longer duration. T2DM is a progressive disease as a result of the complex interplay between insulin resistance and $\beta$-cell dysfunction [81]. The transition from early metabolic abnormalities (e.g., prediabetes) to T2DM may take many years [82]. Lifestyle interventions for T2DM prevention typically involve multiple health related goals (e.g., weight loss, increased physical activity, reduced total and saturated fat intake, increased fibre intake) with the number of goals achieved incrementally decreasing the risk of developing T2DM $[83,84]$. These may explain the reduction in diabetes incidence in interventions of longer follow-up period and higher number of sessions to facilitate the achievement of the multiple diabetes prevention lifestyle goals. Conversely, we found short-term interventions tended to be more effective for weight loss in most ethnic groups. This could be due to weight regain in longer-term studies, which may result from barriers to maintain healthy eating and physical activity behaviours over time [85]. It is documented that most participants in lifestyle programs will regain at least half the weight lost after 2 years and return to their baseline weight after 3 to 5 years [86]. Given weight loss is the primary driver of diabetes risk reduction [83], strategies should be developed to maintain long-term weight loss in each ethnic group. The only potential ethnic difference we noticed was a lower number of sessions associated with better weight loss outcomes in the East and Southeast Asian group. This may reflect a cultural preference, as greater adherence to didactically delivered lifestyle information was found in some Asian subgroups and thus may result in lower intervention dose requirement [87]. However, we were unable to determine the optimal number of sessions for different ethnic groups due to the limited number of studies in each ethnic group; this remains to be confirmed in future research.

This study has several limitations. First, ethnicity was inconsistently described across the studies and as such, we included additional proxies (e.g., race, country of birth, cultural background) to help define ethnicity. Second, the majority of included studies were rated as overall high risk of bias, mainly caused by suboptimal adherence to the interventions. Publication bias was also indicated for the weight outcome. Furthermore, due to the small number of studies in each category of intervention characteristics when stratified by ethnicity, the associations between intervention characteristics and the intervention effects in each ethnic group require further investigation.

In conclusion, this systematic review suggests a high number of sessions is associated with a greater reduction in diabetes incidence and body weight. There may be ethnic preferences for the optimal number of sessions. More research including engagement with stakeholders is needed to develop the most appropriate intervention strategies for T2DM prevention in different ethnic groups. 
Supplementary Materials: The following are available online at https:/ / www.mdpi.com/article / 10.3390/nu13114118/s1, Table S1: coding of the TIDieR components, Table S2: intervention characteristics of included studies according to the TIDieR checklist, Figure S1: flow diagram of included studies, Figure S2: funnel plots for publication bias.

Author Contributions: Conceptualization, S.L., C.L.H., L.J.M. and M.C.; study selection, M.C., G.G.U., S.S. and C.J.B.; data extraction, M.C., G.G.U., S.S. and M.B.K.; study quality assessment, M.C. and C.J.B.; data synthesis, M.C.; writing-original draft preparation, M.C.; writing-review and editing, S.L., C.L.H., L.J.M., H.T., P.A., C.J.B., M.B.K., G.G.U. and S.S.; supervision, S.L., C.L.H. and L.J.M. All authors have read and agreed to the published version of the manuscript.

Funding: This research was funded by the National Health and Medical Research Council Centre for Research Excellence for Health in Preconception and Pregnancy (CRE-HiPP; APP1171142; C.L.H.); National Medical Health and Research Council Fellowship (S.L.); National Heart Foundation Future Leader Fellowship (L.J.M.); Australian Government Medical Research Future Fund Fellowship (H.T.); and Australian Government Research Training Program Scholarship (M.C.). The funders had no role in the design of the study; in the collection, analyses, or interpretation of data; in the writing of the manuscript, or in the decision to publish the results.

Institutional Review Board Statement: Not applicable.

Informed Consent Statement: Not applicable.

Data Availability Statement: The data presented in this study are available in the article and Supplementary Materials.

Acknowledgments: We wish to thank the following authors for providing unpublished data by ethnicity: G. Block (Alive-PD); V. Versace and S. O'Reilly (MAGDA); N.W. Cheung (Smart Mums with Smart Phones). We are also grateful for other authors of the individual studies who responded to our questions and provided additional data for analysis.

Conflicts of Interest: The authors declare no conflict of interest.

\section{References}

1. IDF. IDF Diabetes Atlas, 9th ed.; International Diabetes Federation: Brussels, Belgium, 2019.

2. Spanakis, E.K.; Golden, S.H. Race/Ethnic Difference in Diabetes and Diabetic Complications. Curr. Diabetes Rep. 2013, 13, 814-823. [CrossRef]

3. CDC. National Diabetes Statistics Report, 2020; Centers for Disease Control and Prevention, U.S. Department of Health and Human Services: Atlanta, GA, USA, 2020.

4. Knowler, W.C.; Barrett-Connor, E.; Fowler, S.E.; Hamman, R.F.; Lachin, J.M.; Walker, E.A.; Nathan, D.M. Reduction in the Incidence of Type 2 Diabetes with Lifestyle Intervention or Metformin. N. Engl. J. Med. 2002, 346, 393-403. [CrossRef]

5. Pan, X.-R.; Li, G.-W.; Hu, Y.-H.; Wang, J.-X.; Yang, W.-Y.; An, Z.-X.; Hu, Z.-X.; Lin, J.; Xiao, J.-Z.; Cao, H.-B.; et al. Effects of Diet and Exercise in Preventing NIDDM in People with Impaired Glucose Tolerance: The Da Qing IGT and Diabetes Study. Diabetes Care 1997, 20, 537-544. [CrossRef]

6. Ramachandran, A.; Snehalatha, C.; Mary, S.; Mukesh, B.; Bhaskar, A.D.; Vijay, V.; Indian Diabetes Prevention Programme (IDPP). The Indian Diabetes Prevention Programme shows that lifestyle modification and metformin prevent type 2 diabetes in Asian Indian subjects with impaired glucose tolerance (IDPP-1). Diabetologia 2006, 49, 289-297. [CrossRef]

7. Tuomilehto, J.; Lindström, J.; Eriksson, J.G.; Valle, T.T.; Hämäläinen, H.; Ilanne-Parikka, P.; Keinänen-Kiukaanniemi, S.; Laakso, M.; Louheranta, A.; Rastas, M.; et al. Prevention of Type 2 Diabetes Mellitus by Changes in Lifestyle among Subjects with Impaired Glucose Tolerance. N. Engl. J. Med. 2001, 344, 1343-1350. [CrossRef]

8. Chen, M.; Moran, L.J.; Harrison, C.L.; Ukke, G.G.; Sood, S.; Bennett, C.J.; Bahri Khomami, M.; Absetz, P.; Teede, H.; Lim, S. Ethnic differences in response to lifestyle intervention for the prevention of type 2 diabetes in adults: A systematic review and meta-analysis. Obes. Rev. 2021. [CrossRef] [PubMed]

9. Flanagin, A.; Frey, T.; Christiansen, S.L. AMA Manual of Style Committee Updated Guidance on the Reporting of Race and Ethnicity in Medical and Science Journals. JAMA 2021, 326, 621-627. [CrossRef] [PubMed]

10. Lagisetty, P.A.; Priyadarshini, S.; Terrell, S.; Hamati, M.; Landgraf, J.; Chopra, V.; Heisler, M. Culturally Targeted Strategies for Diabetes Prevention in Minority Population. Diabetes Educ. 2017, 43, 54-77. [CrossRef]

11. Tabak, R.G.; Sinclair, K.A.; Baumann, A.A.; Racette, S.B.; Kuhlmann, A.S.; Johnson-Jennings, M.D.; Brownson, R.C. A review of diabetes prevention program translations: Use of cultural adaptation and implementation research. Transl. Behav. Med. 2015, 5, 401-414. [CrossRef] 
12. Damschroder, L.J.; Aron, D.C.; Keith, R.E.; Kirsh, S.R.; Alexander, J.A.; Lowery, J.C. Fostering implementation of health services research findings into practice: A consolidated framework for advancing implementation science. Implement. Sci. 2009, 4, 1-15. [CrossRef]

13. Ali, M.K.; Echouffo-Tcheugui, J.B.; Williamson, D.F. How Effective Were Lifestyle Interventions in Real-World Settings That Were Modeled on the Diabetes Prevention Program? Health Aff. 2012, 31, 67-75. [CrossRef] [PubMed]

14. Aziz, Z.; Absetz, P.; Oldroyd, J.; Pronk, N.P.; Oldenburg, B. A systematic review of real-world diabetes prevention programs: Learnings from the last 15 years. Implement. Sci. 2015, 10, 1-17. [CrossRef]

15. Dunkley, A.J.; Bodicoat, D.H.; Greaves, C.J.; Russell, C.; Yates, T.; Davies, M.J.; Khunti, K. Diabetes Prevention in the Real World: Effectiveness of Pragmatic Lifestyle Interventions for the Prevention of Type 2 Diabetes and of the Impact of Adherence to Guideline Recommendations. Diabetes Care 2014, 37, 922-933. [CrossRef] [PubMed]

16. Galaviz, K.I.; Weber, M.B.; Straus, A.; Haw, J.S.; Narayan, K.V.; Ali, M.K. Global Diabetes Prevention Interventions: A Systematic Review and Network Meta-analysis of the Real-World Impact on Incidence, Weight, and Glucose. Diabetes Care 2018, 41, 1526-1534. [CrossRef] [PubMed]

17. Greaves, C.J.; Sheppard, K.E.; Abraham, C.; Hardeman, W.; Roden, M.; Evans, P.H.; Schwarz, P. The IMAGE Study Group. Systematic review of reviews of intervention components associated with increased effectiveness in dietary and physical activity interventions. BMC Public Health 2011, 11, 11-12. [CrossRef]

18. Hoffmann, T.C.; Glasziou, P.P.; Boutron, I.; Milne, R.; Perera, R.; Moher, D.; Altman, D.G.; Barbour, V.; Macdonald, H.; Johnston, M.; et al. Better reporting of interventions: Template for intervention description and replication (TIDieR) checklist and guide. BMJ 2014, 348, g1687. [CrossRef] [PubMed]

19. World Bank Data Help Desk. World Bank Country and Lending Groups Data. Available online: https:/ / datahelpdesk.worldbank. org/knowledgebase/articles/906519-world-bank-country-and-lending-groups (accessed on 20 November 2020).

20. Sterne, J.A.C.; Savović, J.; Page, M.J.; Elbers, R.G.; Blencowe, N.S.; Boutron, I.; Cates, C.J.; Cheng, H.-Y.; Corbett, M.S.; Eldridge, S.M.; et al. RoB 2: A revised tool for assessing risk of bias in randomised trials. BMJ 2019, 366, 14898. [CrossRef] [PubMed]

21. Sterne, J.A.; Hernán, M.A.; Reeves, B.C.; Savović, J.; Berkman, N.D.; Viswanathan, M.; Henry, D.; Altman, D.G.; Ansari, M.T.; Boutron, I.; et al. ROBINS-I: A tool for assessing risk of bias in non-randomised studies of interventions. BMJ 2016, 355 , i4919. [CrossRef]

22. Block, G.; Azar, K.M.; Romanelli, R.J.; Block, T.J.; Hopkins, D.; Carpenter, H.A.; Dolginsky, M.S.; Hudes, M.L.; Palaniappan, L.P.; Block, C.H. Diabetes Prevention and Weight Loss with a Fully Automated Behavioral Intervention by Email, Web, and Mobile Phone: A Randomized Controlled Trial Among Persons with Prediabetes. J. Med. Internet Res. 2015, 17, e240. [CrossRef]

23. Cheung, N.W.; Blumenthal, C.; Smith, B.J.; Hogan, R.; Thiagalingam, A.; Redfern, J.; Barry, T.; Cinnadaio, N.; Chow, C.K. A Pilot Randomised Controlled Trial of a Text Messaging Intervention with Customisation Using Linked Data from Wireless Wearable Activity Monitors to Improve Risk Factors Following Gestational Diabetes. Nutrients 2019, 11, 590. [CrossRef]

24. O’Reilly, S.L.; Dunbar, J.A.; Versace, V.; Janus, E.; Best, J.; Carter, R.; Oats, J.J.N.; Skinner, T.; Ackland, M.; Phillips, P.A.; et al. Mothers after Gestational Diabetes in Australia (MAGDA): A Randomised Controlled Trial of a Postnatal Diabetes Prevention Program. PLoS Med. 2016, 13, e1002092. [CrossRef]

25. Auslander, W.; Haire-Joshu, D.; Houston, C.; Rhee, C.-W.; Williams, J.H. A Controlled Evaluation of Staging Dietary Patterns to Reduce the Risk of Diabetes in African-American Women. Diabetes Care 2002, 25, 809-814. [CrossRef] [PubMed]

26. Bernstein, A.; Gendy, G.; Rudd, N.; Doyle, J.; Fay, S.; Moffett, K.; Morrison, S.; Bena, J.; Cotey, S.; Roizen, M.; et al. Management of prediabetes through lifestyle modification in overweight and obese African-American women: The Fitness, Relaxation, and Eating to Stay Healthy (FRESH) randomized controlled trial. Public Health 2014, 128, 674-677. [CrossRef] [PubMed]

27. Aguiar, E.J.; Morgan, P.J.; Collins, C.E.; Plotnikoff, R.C.; Young, M.D.; Callister, R. Efficacy of the Type 2 Diabetes Prevention Using LifeStyle Education Program RCT. Am. J. Prev. Med. 2015, 50, 353-364. [CrossRef] [PubMed]

28. Ramachandran, A.; Snehalatha, C.; Ram, J.; Selvam, S.; Simon, M.; Nanditha, A.; Shetty, A.S.; Godsland, I.F.; Chaturvedi, N.; Majeed, A.; et al. Effectiveness of mobile phone messaging in prevention of type 2 diabetes by lifestyle modification in men in India: A prospective, parallel-group, randomised controlled trial. Lancet Diabetes Endocrinol. 2013, 1, 191-198. [CrossRef]

29. Inouye, J.; Matsuura, C.; Li, N.; Castro, R.; Leake, A. Lifestyle Intervention for Filipino Americans at Risk for Diabetes. J. Community Health Nurs. 2014, 31, 225-237. [CrossRef]

30. West, D.S.; Prewitt, T.; Bursac, Z.; Felix, H.C. Weight loss of black, white, and Hispanic men and women in the diabetes prevention program. Obesity 2008, 16, 1413-1420. [CrossRef]

31. Duijzer, G.; Haveman-Nies, A.; Jansen, S.C.; Ter Beek, J.; Van Bruggen, R.; Willink, M.G.J.; Hiddink, G.J.; Feskens, E.J.M. Effect and maintenance of the SLIMMER diabetes prevention lifestyle intervention in Dutch primary healthcare: A randomised controlled trial. Nutr. Diabetes 2017, 7, e268. [CrossRef]

32. Heideman, W.H.; de Wit, M.; Middelkoop, B.J.; Nierkens, V.; Stronks, K.; Verhoeff, A.P.; Snoek, F.J. Diabetes risk reduction in overweight first degree relatives of type 2 diabetes patients: Effects of a low-intensive lifestyle education program (DiAlert) A randomized controlled trial. Patient Educ. Couns. 2015, 98, 476-483. [CrossRef]

33. Ibrahim, N.; Moy, F.M.; Awalludin, I.A.N.; Ali, Z.M.; Ismail, I.S. Effects of a Community-Based Healthy Lifestyle Intervention Program (Co-HELP) among Adults with Prediabetes in a Developing Country: A Quasi-Experimental Study. PLoS ONE 2016, 11, e0167123. [CrossRef] 
34. Aekplakorn, W.; Tantayotai, V.; Numsangkul, S.; Tatsato, N.; Luckanajantachote, P.; Himathongkam, T. Evaluation of a Community-Based Diabetes Prevention Program in Thailand: A Cluster Randomized Controlled Trial. J. Prim. Care Community Health 2019, 10. [CrossRef] [PubMed]

35. Rollo, M.E.; Aguiar, E.J.; Pursey, K.M.; Morgan, P.J.; Plotnikoff, R.C.; Young, M.D.; Collins, C.E.; Callister, R. Impact on dietary intake of a self-directed, gender-tailored diabetes prevention program in men. World J. Diabetes 2017, 8, 414-421. [CrossRef] [PubMed]

36. Block, G.; Azar, K.M.J.; Romanelli, R.J.; Block, T.; Palaniappan, L.P.; Dolginsky, M.; Block, C.H. Improving diet, activity and wellness in adults at risk of diabetes: Randomized controlled trial. Nutr. Diabetes 2016, 6, e231. [CrossRef]

37. Davies, M.J.; Gray, L.J.; Troughton, J.; Gray, A.; Tuomilehto, J.; Farooqi, A.; Khunti, K.; Yates, T. A community based primary prevention programme for type 2 diabetes integrating identification and lifestyle intervention for prevention: The Let's Prevent Diabetes cluster randomised controlled trial. Prev. Med. 2016, 84, 48-56. [CrossRef] [PubMed]

38. Holmes, V.A.; Draffin, C.R.; Patterson, C.C.; Francis, L.; Irwin, J.; McConnell, M.; Farrell, B.; Brennan, S.F.; McSorley, O.; Wotherspoon, A.C.; et al. Postnatal Lifestyle Intervention for Overweight Women with Previous Gestational Diabetes: A Randomized Controlled Trial. J. Clin. Endocrinol. Metab. 2018, 103, 2478-2487. [CrossRef]

39. Juul, L.; Andersen, V.J.; Arnoldsen, J.; Maindal, H.T. Effectiveness of a brief theory-based health promotion intervention among adults at high risk of type 2 diabetes: One-year results from a randomised trial in a community setting. Prim. Care Diabetes 2016, 10, 111-120. [CrossRef]

40. Kramer, M.K.; Molenaar, D.M.; Arena, V.; Venditti, E.M.; Meehan, R.J.; Miller, R.; Vanderwood, K.K.; Eaglehouse, Y.; Kriska, A. Improving Employee Health. J. Occup. Environ. Med. 2015, 57, 284-291. [CrossRef]

41. Kramer, M.K.; Vanderwood, K.K.; Arena, V.C.; Miller, R.; Meehan, R.; Eaglehouse, Y.L.; Schafer, G.; Venditti, E.M.; Kriska, A. Evaluation of a Diabetes Prevention Program Lifestyle Intervention in Older Adults: A Randomized Controlled Study in Three Senior/Community Centers of Varying Socioeconomic Status. Diabetes Educ. 2018, 44, 118-129. [CrossRef]

42. O'Reilly, S.; Versace, V.; Mohebbi, M.; Lim, S.; Janus, E.; Dunbar, J. The effect of a diabetes prevention program on dietary quality in women with previous gestational diabetes. BMC Women's Health 2019, 19, 1-12. [CrossRef]

43. Peacock, A.S.; Bogossian, F.; Wilkinson, S.; Gibbons, K.; Kim, C.; McIntyre, H.D. A Randomised Controlled Trial to Delay or Prevent Type 2 Diabetes after Gestational Diabetes: Walking for Exercise and Nutrition to Prevent Diabetes for You. Int. J. Endocrinol. 2015, 2015, 1-8. [CrossRef]

44. Roumen, C.; Corpeleijn, E.; Feskens, E.; Mensink, M.; Saris, W.H.M.; Blaak, E.E. Impact of 3-year lifestyle intervention on postprandial glucose metabolism: The SLIM study. Diabet. Med. 2008, 25, 597-605. [CrossRef] [PubMed]

45. Roumen, C.; Feskens, E.; Corpeleijn, E.; Mensink, M.; Saris, W.H.; Blaak, E.E. Predictors of lifestyle intervention outcome and dropout: The SLIM study. Eur. J. Clin. Nutr. 2011, 65, 1141-1147. [CrossRef] [PubMed]

46. den Boer, A.T.; Herraets, I.; Stegen, J.; Roumen, C.; Corpeleijn, E.; Schaper, N.; Feskens, E.; Blaak, E. Prevention of the metabolic syndrome in IGT subjects in a lifestyle intervention: Results from the SLIM study. Nutr. Metab. Cardiovasc. Dis. 2013, 23, 1147-1153. [CrossRef]

47. Weinhold, K.R.; Miller, C.K.; Marrero, D.G.; Nagaraja, H.N.; Focht, B.C.; Gascon, G.M. A randomized controlled trial translating the diabetes prevention program to a university worksite, Ohio, 2012-2014. Prev. Chronic Dis. 2015, 12, 150301. [CrossRef]

48. Miller, C.K.; Weinhold, K.R.; Marrero, D.G.; Nagaraja, H.N.; Focht, B.C. A translational worksite diabetes prevention trial improves psychosocial status, dietary intake, and step counts among employees with prediabetes: A randomized controlled trial. Prev. Med. Rep. 2015, 2, 118-126. [CrossRef]

49. Miller, C.K.; Weinhold, K.R.; Nagaraja, H.N. Impact of a Worksite Diabetes Prevention Intervention on Diet Quality and Social Cognitive Influences of Health Behavior: A Randomized Controlled Trial. J. Nutr. Educ. Behav. 2016, 48, 160-169.e1. [CrossRef]

50. Yates, T.; Edwardson, C.L.; Henson, J.; Gray, L.J.; Ashra, N.B.; Troughton, J.; Khunti, K.; Davies, M. Walking Away from Type 2 diabetes: A cluster randomized controlled trial. Diabet. Med. 2016, 34, 698-707. [CrossRef]

51. Fottrell, E.; Ahmed, N.; Morrison, J.; Kuddus, A.; Shaha, S.K.; King, C.; Jennings, H.; Akter, K.; Nahar, T.; Haghparast-Bidgoli, H.; et al. Community groups or mobile phone messaging to prevent and control type 2 diabetes and intermediate hyperglycaemia in Bangladesh (DMagic): A cluster-randomised controlled trial. Lancet Diabetes Endocrinol. 2019, 7, 200-212. [CrossRef]

52. Islam, N.S.; Zanowiak, J.M.; Wyatt, L.C.; Kavathe, R.; Singh, H.; Kwon, S.; Trinh-Shevrin, C. Diabetes Prevention in the New York City Sikh Asian Indian Community: A Pilot Study. Int. J. Environ. Res. Public Health 2014, 11, 5462-5486. [CrossRef]

53. Lim, S.; Wyatt, L.; Chauhan, H.; Zanowiak, J.M.; Kavathe, R.; Singh, H.; Kwon, S.; Trinh-Shevrin, C.; Islam, N.S. A Culturally Adapted Diabetes Prevention Intervention in the New York City Sikh Asian Indian Community Leads to Improvements in Health Behaviors and Outcomes. Health Behav. Res. 2019, 2, 4. [CrossRef]

54. Limaye, T.; Kumaran, K.; Joglekar, C.; Bhat, D.; Kulkarni, R.; Nanivadekar, A.; Yajnik, C. Efficacy of a virtual assistance-based lifestyle intervention in reducing risk factors for Type 2 diabetes in young employees in the information technology industry in India: LIMIT, a randomized controlled trial. Diabet. Med. 2016, 34, 563-568. [CrossRef]

55. Muralidharan, S.; Ranjani, H.; Anjana, R.M.; Jena, S.; Tandon, N.; Gupta, Y.; Ambekar, S.; Koppikar, V.; Jagannathan, N.; Allender, S.; et al. Engagement and Weight Loss: Results from the Mobile Health and Diabetes Trial. Diabetes Technol. Ther. 2019, 21, 507-513. [CrossRef] 
56. Nanditha, A.; Thomson, H.; Susairaj, P.; Srivanichakorn, W.; Oliver, N.; Godsland, I.F.; Majeed, A.; Darzi, A.; Satheesh, K.; Simon, M.; et al. A pragmatic and scalable strategy using mobile technology to promote sustained lifestyle changes to prevent type 2 diabetes in India and the UK: A randomised controlled trial. Diabetologia 2020, 63, 486-496. [CrossRef]

57. Patel, R.M.; Misra, R.; Raj, S.; Balasubramanyam, A. Effectiveness of a Group-Based Culturally Tailored Lifestyle Intervention Program on Changes in Risk Factors for Type 2 Diabetes among Asian Indians in the United States. J. Diabetes Res. 2017, 2017, 1-13. [CrossRef] [PubMed]

58. Snehalatha, C.; Mary, S.; Joshi, V.V.; Ramachandran, A. Beneficial effects of strategies for primary prevention of diabetes on cardiovascular risk factors: Results of the Indian Diabetes Prevention Programme. Diabetes Vasc. Dis. Res. 2008, 5, 25-29. [CrossRef] [PubMed]

59. Ram, J.; Selvam, S.; Snehalatha, C.; Nanditha, A.; Simon, M.; Shetty, A.S.; Godsland, I.F.; Johnston, D.G.; Ramachandran, A. Improvement in diet habits, independent of physical activity helps to reduce incident diabetes among prediabetic Asian Indian men. Diabetes Res. Clin. Pr. 2014, 106, 491-495. [CrossRef]

60. Nanditha, A.; Snehalatha, C.; Raghavan, A.; Vinitha, R.; Satheesh, K.; Susairaj, P.; Simon, M.; Selvam, S.; Ram, J.; Kumar, A.P.N.; et al. The post-trial analysis of the Indian SMS diabetes prevention study shows persistent beneficial effects of lifestyle intervention. Diabetes Res. Clin. Pr. 2018, 142, 213-221. [CrossRef]

61. Thankappan, K.R.; Sathish, T.; Tapp, R.; Shaw, J.E.; Lotfaliany, M.; Wolfe, R.; Absetz, P.; Mathews, E.; Aziz, Z.; Williams, E.; et al. A peer-support lifestyle intervention for preventing type 2 diabetes in India: A cluster-randomized controlled trial of the Kerala Diabetes Prevention Program. PLoS Med. 2018, 15, e1002575. [CrossRef]

62. Lotfaliany, M.; Sathish, T.; Shaw, J.; Thomas, E.; Tapp, R.J.; Kapoor, N.; Thankappan, K.R.; Oldenburg, B. Effects of a lifestyle intervention on cardiovascular risk among high-risk individuals for diabetes in a low- and middle-income setting: Secondary analysis of the Kerala Diabetes Prevention Program. Prev. Med. 2020, 139, 106068. [CrossRef]

63. Weber, M.B.; Ranjani, H.; Staimez, L.R.; Anjana, R.M.; Ali, M.K.; Narayan, K.V.; Mohan, V. The Stepwise Approach to Diabetes Prevention: Results From the D-CLIP Randomized Controlled Trial. Diabetes Care 2016, 39, 1760-1767. [CrossRef] [PubMed]

64. Bender, M.S.; Cooper, B.A.; Flowers, E.; Ma, R.; Arai, S. Filipinos Fit and Trim-A feasible and efficacious DPP-based intervention trial. Contemp. Clin. Trials Commun. 2018, 12, 76-84. [CrossRef]

65. Islam, N.S.; Zanowiak, J.M.; Wyatt, L.C.; Chun, K.; Lee, L.; Kwon, S.; Trinh-Shevrin, C. A randomized-controlled, pilot intervention on diabetes prevention and healthy lifestyles in the New York City Korean community. J. Community Health 2013, 38, $1030-1041$. [CrossRef]

66. Moungngern, Y.; Sanguanthammarong, S.; Teparak, P.; Sriwijitkamol, A. Effects of a health promotion program conducted by nurses on stabilization of HBA1C in subjects at risk for diabetes: A phase III randomized controlled trial. J. Med. Assoc. Thail. 2018, 101, 1343-1348.

67. Pan, X.; Li, G.; Hu, Y. Effect of dietary and/or exercise intervention on incidence of diabetes in 530 subjects with impaired glucose tolerance from 1986-1992. Zhonghua Nei Ke Za Zhi 1995, 34, 108-112.

68. Li, G.; Zhang, P.; Wang, J.; Gregg, E.W.; Yang, W.; Gong, Q.; Li, H.; Li, H.; Jiang, Y.; An, Y.; et al. The long-term effect of lifestyle interventions to prevent diabetes in the China Da Qing diabetes prevention study: A 20-year follow-up study. Lancet 2008, 371, 1783-1789. [CrossRef]

69. Sakane, N.; Japan Diabetes Prevention Program (JDPP) Research Group; Sato, J.; Tsushita, K.; Tsujii, S.; Kotani, K.; Tsuzaki, K.; Tominaga, M.; Kawazu, S.; Sato, Y.; et al. Prevention of type 2 diabetes in a primary healthcare setting: Three-year results of lifestyle intervention in Japanese subjects with impaired glucose tolerance. BMC Public Health 2011, 11, 40. [CrossRef]

70. Sakane, N.; Sato, J.; Tsushita, K.; Tsujii, S.; Kotani, K.; Tominaga, M.; Kawazu, S.; Sato, Y.; Usui, T.; Kamae, I.; et al. Effect of baseline $\mathrm{HbA1c}$ level on the development of diabetes by lifestyle intervention in primary healthcare settings: Insights from subanalysis of the Japan Diabetes Prevention Program. BMJ Open Diabetes Res. Care 2014, 2, e000003. [CrossRef]

71. Shek, N.W.M.; Ngai, C.S.W.; Lee, C.P.; Chan, J.Y.C.; Lao, T.T.H. Lifestyle modifications in the development of diabetes mellitus and metabolic syndrome in Chinese women who had gestational diabetes mellitus: A randomized interventional trial. Arch. Gynecol. Obstet. 2013, 289, 319-327. [CrossRef]

72. Wong, C.K.; Fung, C.S.; Siu, S.; Lo, Y.Y.; Wong, K.; Fong, D.Y.; Lam, C.L. A short message service (SMS) intervention to prevent diabetes in Chinese professional drivers with pre-diabetes: A pilot single-blinded randomized controlled trial. Diabetes Res. Clin. Pr. 2013, 102, 158-166. [CrossRef]

73. Abujudeh, B.A.; Abu Al Rub, R.F.; Al-Faouri, I.G.; Gharaibeh, M.K. The impact of lifestyle modification in preventing or delaying the progression of type 2 diabetes mellitus among high-risk people in Jordan. J. Res. Nurs. 2010, 17, 32-44. [CrossRef]

74. Al-Hamdan, R.; Avery, A.; Salter, A.; Al-Disi, D.; Al-Daghri, N.M.; McCullough, F. Identification of Education Models to Improve Health Outcomes in Arab Women with Pre-Diabetes. Nutrients 2019, 11, 1113. [CrossRef] [PubMed]

75. Amer, O.E.; Sabico, S.; Alfawaz, H.A.; Aljohani, N.; Hussain, S.D.; Alnaami, A.M.; Wani, K.; Al-Daghri, N.M. Reversal of Prediabetes in Saudi Adults: Results from an 18 Month Lifestyle Intervention. Nutrients 2020, 12, 804. [CrossRef]

76. Zilberman-Kravits, D.; Meyerstein, N.; Abu-Rabia, Y.; Wiznitzer, A.; Harman-Boehm, I. The Impact of a Cultural Lifestyle Intervention on Metabolic Parameters After Gestational Diabetes Mellitus A Randomized Controlled Trial. Matern. Child Health J. 2018, 22, 803-811. [CrossRef] [PubMed] 
77. Ockene, I.S.; Tellez, T.L.; Rosal, M.C.; Reed, G.W.; Mordes, J.P.; Merriam, P.A.; Olendzki, B.; Handelman, G.; Nicolosi, R.J.; Ma, Y. Outcomes of a Latino Community-Based Intervention for the Prevention of Diabetes: The Lawrence Latino Diabetes Prevention Project. Am. J. Public Health 2012, 102, 336-342. [CrossRef]

78. Parikh, P.; Simon, E.P.; Fei, K.; Looker, H.; Goytia, C.; Horowitz, C.R. Results of a Pilot Diabetes Prevention Intervention in East Harlem, New York City: Project HEED. Am. J. Public Health 2010, 100, S232-S239. [CrossRef]

79. Van Name, M.A.; Camp, A.W.; Magenheimer, E.A.; Li, F.; Dziura, J.D.; Montosa, A.; Patel, A.; Tamborlane, W.V. Effective Translation of an Intensive Lifestyle Intervention for Hispanic Women with Prediabetes in a Community Health Center Setting. Diabetes Care 2016, 39, 525-531. [CrossRef]

80. Auslander, W.; Haire-Joshu, D.; Houston, C.; Williams, J.H.; Krebill, H. The short-term impact of a health promotion program for low-income African American women. Res. Soc. Work Pract. 2000, 10, 78-97. [CrossRef]

81. Galaviz, K.I.; Narayan, K.M.V.; Lobelo, F.; Weber, M.B. Lifestyle and the Prevention of Type 2 Diabetes: A Status Report. Am. J. Lifestyle Med. 2015, 12, 4-20. [CrossRef]

82. Nathan, D.M.; Davidson, M.B.; De Fronzo, R.A.; Heine, R.J.; Henry, R.R.; Pratley, R.; Zinman, B. Impaired Fasting Glucose and Impaired Glucose Tolerance: Implications for care. Diabetes Care 2007, 30, 753-759. [CrossRef]

83. Hamman, R.F.; Wing, R.R.; Edelstein, S.L.; Lachin, J.M.; Bray, G.A.; Delahanty, L.; Hoskin, M.; Kriska, A.M.; Mayer-Davis, E.J.; Pi-Sunyer, X.; et al. Effect of Weight Loss with Lifestyle Intervention on Risk of Diabetes. Diabetes Care 2006, 29, $2102-2107$. [CrossRef]

84. Lindström, J.; Ilanne-Parikka, P.; Peltonen, M.; Aunola, S.; Eriksson, J.; Hemiö, K.; Hämäläinen, H.; Härkönen, P.; KeinänenKiukaanniemi, S.; Laakso, M.; et al. Sustained reduction in the incidence of type 2 diabetes by lifestyle intervention: Follow-up of the Finnish Diabetes Prevention Study. Lancet 2006, 368, 1673-1679. [CrossRef]

85. Greenway, F.L. Physiological adaptations to weight loss and factors favouring weight regain. Int. J. Obes. 2015, 39, 1188-1196. [CrossRef]

86. Stelmach-Mardas, M.; Mardas, M.; Walkowiak, J.; Boeing, H. Long-term weight status in regainers after weight loss by lifestyle intervention: Status and challenges. Proc. Nutr. Soc. 2014, 73, 509-518. [CrossRef]

87. Wan, C.S.; Teede, H.; Nankervis, A.; Aroni, R. Ethnic Differences in Dietary Management of Gestational Diabetes Mellitus: A Mixed Methods Study Comparing Ethnic Chinese Immigrants and Australian Women. J. Acad. Nutr. Diet. 2019, 120, 86-102. [CrossRef] 